\title{
Corporatization and Privatization of Malaysian Higher Education
}

\section{Molly N. N. Lee}

Molly N. N. Lee is associate professor of education at the Science University of Malaysia. Address: School of Education, Universiti Sains Malaysia, 11800 USM, Pulau Pinang, Malaysia. Fax: 04-657-2907.

$\mathrm{O}$ n January 1, 1998, University of Malaya, the oldest university in Malaysia, was corporatized, as will, in due course, all eight public universities in the country. But what will corporatization mean for Malaysia's universities?

Corporatized universities will be allowed to borrow money, enter into business ventures, set up companies, and acquire and hold investment shares.

\section{Corporatizing the Ivory Tower}

Corporatized universities will be allowed to borrow money, enter into business ventures, set up companies, and acquire and hold investment shares. The government will continue to own most of the universities' existing assets, and to provide development funds for new programs, and expensive capital projects. But the universities will assume the burden of raising a major portion of their operating costs.

Corporatized universities are expected to raise funds through a variety of revenue-generating activities—such as, raising tuition fees, increasing student enrollments, conducting consultancies for industry and government, running short-tern courses to meet the needs of the private sector, and renting out facilities. These changes are aimed at developing alternative funding sources for higher education, and reducing the financial dependence on the government.

The penetration of corporate culture into the university has generated much anxiety among academics, who fear that the many entrepreneurial activities will impair the academic quality and freedom of the university. Yet, advocates of the corporatization argue that, with these changes, universities will gain greater financial and administrative autonomy. By offering attractive salary packages for academic staff, corporatized universities may prevent the "brain drain" of academics to the private sector. The most frequently cited rationale for corporatization in Malaysia is the need to free the university from the cumbersome bureaucratic processes of the civil service. However, the real crux of the matter is that, over the past decade, with the introduction of universal secondary education, has come an increasing social demand for higher education that the government has been hard-pressed to meet. It was to overcome this problem that the Malaysian government turned to the market for a solution, and to privatizing higher education.

\section{Private-Sector Innovations}

Besides the move to corporatize public universities, the government has relaxed restrictions on the establishment of private institutions of higher learning. The 1990s saw a rapid expansion in the number and types of private colleges, in student enrollments, and in the scope of courses offered.

The private education sector has been very innovative in adapting to rapidly changing student demand and public policies on higher education. In Malaysia, the 1969 Essential (Higher Education Institution) Regulation barred private institutions from conferring degrees, and foreign universities from setting up branch campuses in the country. Thus, many of the private colleges instead forged institutional links with foreign universities to offer various types of degree and professional programs.

These foreign-linkages come in the form of twinning degree programs, credit transfer degree programs, external degree programs, and joint programs. Many allow a student to study part of the program in a local private college before proceeding to the foreign university to complete the program. Upon completion of the program, a degree is conferred by the foreign university.

\section{The penetration of corporate culture into the university has generated much anxi- ety among academics, who fear that the many entrepreneurial activities will im- pair the academic quality and freedom of the university.}

The main attraction of these programs has been the reduced cost of obtaining a foreign degree. A student can save from U.S.\$4,000 to U.S.\$10,000 per year by enrolling in a twinning program at a local college instead of studying abroad during the initial part of the program.

\section{Quality Controls}

The quality of foreign-linked programs has always been an issue among parents and educators. Concerns have been raised as to whether the quality of twinning programs mea- 
sured up to similar programs offered at the particular foreign university. No doubt the expansion of private higher education has increased access, but has this occurred at the expense of quality and equity and do less-privileged students pay more for an inferior education provided by the private sector?

In an effort to exercise some quality control over private higher education, the Malaysian government requires all private colleges to register with the Ministry of Education and to obtain ministry approval for any new programs.

In an effort to exercise some quality control over private higher education, the Malaysian government requires all private colleges to register with the Ministry of Education and to obtain ministry approval for any new programs. The ministry can impose fines or even close down colleges for not complying with regulations-such as, employing a noncertified lecturer or conducting classes in buildings that do not meet safety codes. However, lack of resources prevents the ministry from fully monitoring and enforcing the rules and regulations pertaining to private education. The Malaysian government faces a dilemma of having to liberalize and privatize education while, at the same time, regulating and controlling the system to ensure quality and equity.

\section{Many developing countries tend to ne- glect their cultural heritage in their hurry to modernize and develop economically, while others see globalization as harm- ful to the moral and cultural well-being of the nation.}

\section{Cultural Issues}

There is a growing trend toward the globalization of higher education. Advanced countries are keen to export their educational programs, and developing countries are prepared to franchise these programs. These programs not only equip local people with the knowledge and skills to participate in the global economy but also transmit global cultural values and attitudes—such as, competitiveness, self- efficiency, high achievement motivation, and an acceptance of the importance of the English language. The curriculum has become a matter of great concern in countries like Malaysia, which view the transmission of the global culture as part of the dominance of Western culture. In response, the Malaysian government has introduced educational policies intended to give higher education a Malaysian identity. All private colleges must conduct their courses in the national language, and if they want to conduct any course in English, they must teach Malaysian studies (including Islamic and Asian civilizations), Islamic studies (for Muslim students), and moral education (for non-Muslim students).

Many developing countries tend to neglect their cultural heritage in their hurry to modernize and develop economically, while others see globalization as harmful to the moral and cultural well-being of the nation. The challenge is how to achieve a balance between the inevitability of accepting the global culture and the need to safeguard cultural identity. Educators must choose what is necessary in the way of knowledge and skills for meeting the challenges of changing world order, while preserving as much of the country's cultural heritage as possible.

\section{Student Magna Carta Results in Philippine Private Higher Education Protest}

\section{Andrew Gonzalez, FSC}

Bro. Andrew Gonzalez, FSC, is president of De La Salle University, Manila, Philippines. Address: 1501 Taft Ave., Manila, Philippines.

$\mathrm{P}$ rivate colleges and universities in the Philippines were closed late last year for a day of silent protest. Following the October 12, 1997 congressional ratification of a "Magna Carta" for students (House Bill Number 9935), the country's Coordinating Council of Private Educational Associations (CCPEA) - a national federation of sectarian and proprietary colleges and universities-called for the action to make public their concerns about several provisions in the new Bill. Administrators of the country's almost 1,000 private colleges and universities fear that the student Magna Carta could jeopardize their ability to manage and to keep schools viable.

The Bill's provisions found to be especially objectionable to the administrators included the ex officio membership on Boards of Regents/Trustees for student government heads; student membership on the School Fee Board-a committee able to overrule an institution's Board of Trustees; the right of students to overturn unpopular administrative policies by referendum; and, 